\title{
Importance of Pre-Operative COVID 19 Screening of Asymptomatic Patients Undergoing Maxillofacial Surgery
}

\author{
SMA SADAT ${ }^{\mathrm{a}}, \mathrm{M}^{\mathrm{B} A D R U D D O Z A^{\mathrm{b}}}$
}

\begin{abstract}
:
COVID-19 usually presents with fever, coughs dyspnea, myalgia, and fatigue and may infect people of any age though older people with co morbidities are more vulnerable. But many carriers do not present any symptoms. Operating on undiagnosed COVID-19 patients may cause exposure of medical staff in ward and theatre. $A$ cross sectional was done on 100 consecutive cases suffering from oral and maxillofacial pathologies from 20 $0^{\text {th }}$ May 2020 to $28^{\text {th }}$ August 2020, recruited from Oral and Maxillofacial Surgery department of
\end{abstract}

Introduction:

A novel coronavirus was identified as the cause of many pneumonia cases in Wuhan, China in December $2019^{1}$. The new virus, COVID-19 usually presents with fever, coughs dyspnea, myalgia, and fatigue and may infect people of any age $\mathrm{e}^{2,3}$. But many carriers do not present any symptoms $\mathrm{s}^{3,4}$. During the current pandemic, it is recommended to postpone all elective surgeries in addition to guidance on infection control and prevention ${ }^{5-7}$. Emergency and urgent surgeries like oral cancers, maxillofacial trauma, active bleeding and Orofacial infections are still being performed. Operating on COVID-19 patients may cause exposure of medical staff in ward and

a. Dr. S. M. Anwar Sadat, BDS, MCPS, FCPS, MS (OMS), Associate Professor, Oral \& Maxillofacial Surgery, Dhaka Dental College; Consultant, Square Hospitals Ltd, Dhaka, Bangladesh

b. Dr. Muhammad Badruddoza, BDS, Resident, Oral \& Maxillofacial Surgery, Dhaka Dental College, Dhaka, Bangladesh

Address of Correspondence: Dr. S. M. Anwar Sadat, BDS, MCPS, FCPS, MS (OMS), Associate Professor, Oral \& Maxillofacial Surgery, Dhaka Dental College, Consultant, Square Hospitals Ltd, Dhaka, Bangladesh, Cell: +8801711156023, E-mail: an_sadat@yahoo.com

Received: 31 May, 2020

Accepted: 08 September, 2020

\begin{abstract}
Dhaka Dental College Hospital and Square Hospitals Ltd, Dhaka, Bangladesh. Out of 100 cases, 7 were affected (7\%) by COVID 19 confirmed by RT-PCR in pre-operative screening.Preoperative COVID 19 screening of asymptomatic patients should be considered to improve patient and provider safety and reduce the cost of resource.
\end{abstract}

Key Words: COVID 19, Maxillofacial Surgery, Screening

(J Bangladesh Coll Phys Surg 2020; 38: 229-231)

DOI: https://doi.org/10.3329/jbcps.v38i4.49358

theatre. So, all surgical candidate patients must complete preoperative universal health screening for known or unknown symptoms of COVID-19 recommended by different surgical societies ${ }^{6,8}$. The purpose of this document is to highlight the percentage of COVID 19 positive asymptomatic cases detected in pre-operative screening and its justification before undergoing maxillofacial surgeries.

Materials and Methods:

A cross sectional is done on 100 consecutive cases suffering from oral and maxillofacial pathologies from $20^{\text {th }}$ May 2020 to $28^{\text {th }}$ August 2020, recruited from Oral and Maxillofacial Surgery department of Dhaka Dental College Hospital and Square Hospitals Ltd, Dhaka, Bangladesh.

\section{Results:}

Among 100 cases, 80 cases were recruited from Oral and Maxillofacial Surgery department of Dhaka Dental College and 20 cases from Square Hospitals Ltd, Dhaka, Bangladesh. Male and female cases were almost same (M: $\mathrm{F}=1.3: 1)$. Age ranges from 5 years to 80 years with average age 40 years. Data showed case distribution as Oral Cancer (38), Facial Injury (30), Benign Tumor (20), Infection of Orofacial soft and hard tissue (10), Ankylosis of TMJ (1) and impacted wisdom teeth (1). Out of 100 cases, 7 were 
affected (7\%) by COVID 19 confirmed by RT-PCR in pre-operative screening.

Among 7 Covid positive cases, 5 were oral cancer, 1 was benign tumor and 1 was infection (Chronic Osteomyelitis). All cases were asymptomatic and needed no treatment for COVID related problems. All these cases were treated accordingly for their primary diseases and discharged uneventfully.

Table 1: Demographic features of patients $(\mathbf{n}=\mathbf{1 0 0})$

\begin{tabular}{|c|c|c|}
\hline Age & $\begin{array}{l}\text { Mean: } \\
\text { Range: }\end{array}$ & $\begin{array}{l}40 \text { Years } \\
5-80 \text { years }\end{array}$ \\
\hline Gender & $\begin{array}{l}\text { Male } \\
\text { Female }\end{array}$ & $\begin{array}{l}57(57 \%) \\
43(43 \%)\end{array}$ \\
\hline Socio-economic status & $\begin{array}{l}\text { Upper class } \\
\text { Lower class }\end{array}$ & $\begin{array}{l}20(20 \%) \\
80(80 \%)\end{array}$ \\
\hline Types of Disease & $\begin{array}{l}\text { Oral Cancer } \\
\text { Facial Injury } \\
\text { Benign Tumor } \\
\text { Orofacial Infection } \\
\text { Ankylosis of TMJ } \\
\text { Impacted wisdom teeth }\end{array}$ & $\begin{array}{l}38(38 \%) \\
30(30 \%) \\
20(20 \%) \\
10(10 \%) \\
1(1 \%) \\
1(1 \%)\end{array}$ \\
\hline
\end{tabular}

Table 2: Distribution of asymptomatic COVID 19 positive cases $(n=7)$

\begin{tabular}{|l|l|l|}
\hline Gender & Male & $\begin{array}{l}2(28.5 \%) \\
5(71.5 \%)\end{array}$ \\
\hline Female & Upper class - affected & $\begin{array}{l}3 / 20,15 \% \\
4 / 80,5 \%\end{array}$ \\
\hline Lower class - affected & 5 \\
& Oral cancer & 1 \\
& Benign Tumor & 1 \\
\hline
\end{tabular}

\section{Discussion:}

Specialties such as maxillofacial surgery, ENT and clinical dentistry need to provide sufficient facilities and personal protective equipment to protect patients and health care providers from exposure of COVID $19{ }^{9}$. Due to unknown number of asymptomatic COVID 19 positive patients, all patients seeking for surgical treatment should be taken as potentially infective $^{10}$. The facility of accurate SARS-CoV-2 testing would be a significant step in separating infected patients from non-infected patients. As seen in our study, there were $7 \%$ positive asymptomatic patients who underwent maxillofacial surgeries. So, routine pre-operative screening prior to elective surgery has been broadly discussed. According to American guidelines, including the Endoscopic
Surgeons (SAGES), Society of Gynecologic Oncology (SGO) and the Society of American Gastrointestinal, preoperative patients should be tested for COVID-19, regardless of their symptoms or exposure ${ }^{11,12}$.

Identifying SARS-CoV-2 carriers before surgery has benefit to prevent adverse patient events, prevent further transmission, reduce need of personal protective equipment, and improve hospital system efficiency. The disadvantage associated with routine testing are less frequently considered. The objective of SARS-CoV-2 screening with RT-PCR is to detect viral genetic material (RNA) in the pre symptomatic phase of infection. This incubation period for SARS-CoV-2 is protracted with initial low levels of viral RNA until replication increases in the hours or days leading up to appearance of symptom ${ }^{13}$. Logarithmic viral replication and subsequent symptoms only start five to six days after exposure, but often this can be delayed up to 14 days ${ }^{14}$. Before viral RNA reaches detectable thresholds, patients may appear well prior to elective surgery despite being exposed to SARS-CoV-2 in the preceding 14 days. If viral carriage is not detected by testing, patients may proceed with elective surgery whereby signs and symptoms of COVID-19 may arise in the post-operative period, leading to adverse effects ${ }^{15}$.

Conclusion: COVID-19 may have potential serious complications on the perioperative period and may result in fatal outcome in some situation. From our findings, a good percentage of asymptomatic patients were detected as COVID positive and so preoperative COVID 19 screening of asymptomatic patients should be considered especially in high prevalence areas to improve patient and provider safety and reduce the cost of resource. In addition to testing, alternative strategies that include self-isolation and other distancing measures with universal precaution of considering all cases as COVID positive and protection accordingly are needed to prevent cross infection to health care providers.

\section{References:}

1. Tan W, Zhao X, Ma X et al (2020). A novel coronavirus genome identified in a cluster of pneumonia cases-Wuhan, China 2019-2020. China CDC Wkly 2:61-62

2. Young BE, Ong SWX, Kalimuddin S et al (2020) Epidemiologic features and clinical course of patients infected with SARS-CoV2 in Singapore. JAMA J Am Med Assoc. https://doi.org/10.1001/ jama.2020.3204 
3. Greenland JR, Michelow MD, Wang L, London MJ (2020) COVID-19 infection: implications for perioperative and critical care physicians. Anesthesiology. https://doi.org/10.1097/ALN. 000000000003303

4. Zou L, Ruan F, Huang M et al (2020) SARS-CoV-2 viral load in upper respiratory specimens of infected patients. N Engl J Med. https://doi.org/10.1056/NEJMc2001737

5. ACS COVID-19: Recommendations for Management of Elective Surgical Procedures. Publ March 13, 2020 facs.org/covid19/clinical-guidance/elective-case/cancersurgery

6. Dowdy S, Fader AN Surgical Considerations for Gynecologic Oncologists During the COVID-19 Pandemic. 1-4

7. ESSO Statement on COVID-19 Advice for surgical oncologists on cancer service. Publ March 27, 2020 https//www.essoweb.org/news/esso-statement-covid-19/

8. Pryor A sages and EAES recommendations regarding surgical response TO Rationing of Services: procedural Considerations: Publ March 29, 2020 https//www.sages.org/ recommendationssurgical-response-covid-19/

9. Chan, J. F., Yuan, S. F., Kok, K. H., To, K. K., Chu, H., Yang, J., et al. (2020b). A familial cluster of pneu-monia associated with the 2019 novel coronavirus indicating person-to-person transmission: a study of a family cluster. Lancet 395, 514-523. doi: 10.1016/ S0140-6736 (20)30154-912.

10. Rothe C, Schunk M, Sothmann P, Bretzel G, Froeschl G, Wallrauch C, et al: Transmission of 2019-nCoVinfection from an asymptomatic contact in Germany. N Engl J Med 382: 970e971, 2020

11. Dowdy S, Fader AN Surgical Considerations for Gynecologic Oncologists During the COVID-19 Pandemic. 1-4

12. Pryor A sages and EAES recommendations regarding surgical response TO Rationing of Services: procedural Considerations: Publ March 29, 2020 https//www.sages.org/ recommendationssurgical-response-covid-19/

13. He X, Lau EH, Wu P,et al. Temporal dynamics in viral shedding and transmissibility of COVID-19. Nat Med 2020; 26: 672-5.

14. Linton NM, Kobayashi T, Yang $\mathrm{Y}$, et al. Incubation period and other epidemiological characteristics of, 2019 novel corona virus infections with right truncation: a statistical analysis of publicly available case data. J Clin Med 2020; .https://doi.org/10.3390/jcm9020538.

15. Lei S, Jiang F, Su W, et al. Clinical characteristics and outcome of patients undergoing surgeries during the incubation period ofCOVID-19 infection. E Clinical Medicine 2020; .https://doi.org/10.1016/ j.eclinm.2020.100331. 